Міщенко Алла Борисівна

кандидат політичних наук,

Київський національний університет культури і мистецтвв,

Київ, Украӥна,

mishenko.ab@gmail.com

\title{
ЗОВНІШНЯ ПОЛІТИКА КРІЗЬ ПРИЗМУ ГРОМАДСЬКОЇ ДУМКИ
}

У статті досліджуються багатоаспектні особливості впливу громадської думки на формування й реалізацію зовнішньополітичної діяльності країни. Використовувався міждисциплінарний підхід, який поєднав напрацювання 3 соціології, права, політології та міжнародних відносин. На основі історичного методу вдалося екстраполювати отримані практики XX ст. щодо врахування суспільної думки на сучасні міжнародні події, системний метод визначив державу як суб'єкта міжнародних відносин, враховуючи окрему роль іiі інститутів, порівняльний метод дозволив вирізнити особливості впливу громадян на державні рішення у різних політичних режимах, а біхевіористський - дозволив виокремити умови зміни поведінки громадян, суспільства щодо зовнішньої політики. Здійснений аналіз наукових підходів реалізму та лібералізму визначив історичні епохи їх формування та основні тенденції врахування або ігнорування настроїв громадян на рівні державної політики щодо короткострокових та стратегічних завдань влади в реалізації ії зовнішньої політики. Було визначено групи країн, де вони найбільш відображаються. Важливим висновком дослідження, відповідно, стало окреслення маніпулятивної складової формування громадської думки за допомогою ЗМІ, особливо демократичними країнами, щодо найбільш важливих подій типу вторгнення в іншу країну, коаліційна участь у міжнародних конфліктах, інтервенція, членство в міжурядових організаціях тощо. Відповідно, було доведено, що громадська думка $є$ важливим процесом легітимації зовнішньополітичної діяльності держави як всередині держави, так і у взаємодії з міжнародними акторами.

Ключові слова: громадська думка, зовнішня політика, легітимація, лібералізм, маніпуляція, реалізм

Mishchenko Alla, Candidate of Political Sciences, Kyiv National University of Culture and Arts, Kyiv, Ukraine

\section{Foreign policy through the prism of public opinion}

The article investigates the multidimensional features of the public opinion influence on forming and realization of the foreign-policy activity of the country. The interdisciplinary approach, that connected work from sociology, law, political science andinternational relations, was used. On the basis of historical method, it was succeeded to extrapolate the received practices of the XXth century as for taking into account of public idea on modern international events, a system method defined the state as a subject of international relations, taking into account the separate role of its institutes, a comparative method allowed to distinguish the features of influence of citizens on state decisions in the different political modes, and behaviorism allowed to distinguish the terms of change of the citizens' behavior, society in relation to a foreign policy. The realized analysis of the scientific approaches of realism and liberalism defined the historical epochs of their forming and basic tendencies of taking into account or ignoring the citizens' moods at the level of the public policy in relation to the short-term and strategic tasks of power in its international cooperation. The groups of countries were certain, where they are most represented. It has been found that, the delineation of manipulative constituent of forming the public opinion became the important conclusion of the research by means of mass-media, by specially democratic countries, in relation to the most essential events as intruding in the other country, coalition participating in international conflicts, intervention, membership in intergovernmental organizations and others like that. Thereafter, it was well-proven that the public opinion is the important process of the 
legitimacy of the foreign-policy activity of the state both inside the state and in cooperating with international players.

Key words: public opinion; foreign policy; legitimation; liberalism; manipulation; realism.

Мищенко Алла Борисовна, кандидат политических наук, Киевский начиональный университет культуры и искусств, Киев, Украина

\section{Внешняя политика сквозь призму общественного мнения}

В статье исследуются многоаспектные особенности влияния общественного мнения на формирование и реализацию внешнеполитической деятельности страны. Использовался междисциплинарный подход, который соединил наработки по социологии, праву, политологии и международных отношениях. На основе исторического метода удалось экстраполировать полученные практики XX века по учету общественного мнения в отношении современных международных событий, системный метод определил государство как субъекта международных отношений, учитывая отдельную роль ее институтов, сравнительный метод позволил выделить особенности влияния граждан на государственные решения в различных политических режимах, a бихевиористский - позволил выделить условия изменения поведения граждан, общества в отношении внешней политики. Проведенный анализ научных подходов реализма и либерализма определил исторические эпохи их формирования и основные тенденции учета или игнорирования настроений граждан на уровне государственной политики по краткосрочным и стратегическим задачам власти в реализации ее внешней политики. Было определено группы стран, где они наиболее отображаются. Важным выводом исследования, соответственно, стало определение манипулятивной составляющей формирования общественного мнения с помощью СМИ, особенно демократическими странами, по наиболее важным событиям таким как вторжение в другую страну, коалиционное участие в международных конфликтах, интервенция, членство в межправительственных организациях и т. д. Соответственно, было доказано, что общественное мнение является важным процессом легитимации внешнеполитической деятельности государства как внутри государства, так и во взаимодействии с международными актерами.

Ключевые слова: общественное мнение; внешняя политика; легитимация; либерализм; манипуляция; реализм

Вступ. Система комунікативної діяльності між суспільством як суб'єктом впливу та державою набула широкої популяризації у XXI ст., враховуючи необхідність пошуку ефективних механізмів формування горизонтальної взаємодії між двома важливими учасниками політичного процесу. Враховуючи динамізм всепоглинаючої глобалізації та відсутність абсолютно ізоляціоністських країн на політичній карті світу, стало важливо здійснити аналіз процесу впливу громадської думки, настроїв різноманітних соціальних груп при здійсненні не лише внутрішньої, а особливо зовнішньополітичної активності країни на міжнародній арені. Використання таких словосполучень як «довіра громадян до...», «ставлення громадян до...», «реакція суспільства на...» і т. д. стали повсякденними серед більшості державних службовців та політичних діячів 3 метою посилення позиції або виправдання певних кроків в процесі прийняття ними поточних $\mathrm{i}$ стратегічних рішень.

Відповідно, потребує доведення теза, що громадська думка дозволяє певною мірою маніпулювати процесом формування та реалізації зовнішньої політики держави і легітимізувати дії влади щодо інших акторів в системі міжнародних відносин.

Аналіз останніх досліджень і публікацій. Для детального та якісного дослідження даного питання було використано міждисциплінарний підхід, що дозволили використати наукові підходи та методологію різних наук. Зокрема, щодо визначення поняття «громадська думка», «соціальні особливості розвитку», «тиск громадськості», «суспільне бачення» було досліджено праці вченихсоціологів вітчизняного та іноземного походження, а саме: В. Іванов, Л. Ляпіна, О. Ляпіна, Б. Пейдж, Р. Шапіро, В. Полторак, В. Оссовський, В. Шатун і т. д. 
Виокремлення глобалізаційних процесів, їх вплив на формування внутрішньої та зовнішньої політики держави та дослідження наслідків і закономірностей такої діяльності було об'єктом дослідження таких вчених політологів, міжнародників, правознавців як: О. Арін, М. Багмет, 3. Бжезинський, Г. Моргентау, Г. Кіссінджер, Дж. Ньюман, І. Панарін, П. Циганков тощо.

Виділення невирішених частин проблеми. Незважаючи на велику кількість досліджень окремих аспектів ролі громадськості, формування суспільної думки, майже відсутні комплексні дослідження щодо впливу такого феномену як надіндивідуальне бачення щодо пріоритетного розвитку країни, прийняття державних стратегій і тактик, особливо в процесі реалізації зовнішньополітичної діяльності через низку нормативно-правових та політичних рішень.

Відповідно, метою дослідження $є$ аналіз впливу громадської думки на формування та реалізацію зовнішньої політики держави.

Головними завданнями статті, відповідно, є наступні:

- виокремити основні підходи до розуміння важливості громадської думки при виробленні та впровадженні окремих аспектів зовнішньополітичної діяльності;

- здійснити огляд наукових підходів щодо місця й ролі громадської думки щодо міжнародної діяльності країни;

- проаналізувати відмінності впливу громадської думки на зовнішню політику держави в різних політичних режимах;

- довести гіпотезу, що громадська думка у XXI ст. $є$ засобом вмілого маніпулювання та легітимізації дій влади.

Основними методами дослідження, крім загальнонаукових, стали: історичний, який дозволив ознайомитися 3 підходами попередніх століть та екстраполювати отримані закономірності та практики щодо сучасних подій (наприклад, стан розвитку суспільств попередніх століть був вкрай низьким щодо можливого свідомого заперечення обраного курсу держави, зносин чи ведення військових дій з конкретним ворогом); системний, який сприяв комплексному розгляду держави як суб'єкта міжнародних відносин, а також ії окремих інститутів при здійсненні суто зовнішньої політики; порівняльний - при оцінці стану та якості громадської думки в різних політичних режимах; біхевіористський, який дозволив виокремити поведінкові особливості різноманітних груп громадян або суспільства загалом щодо конкретних подій та рішень влади.

Виклад основного тексту дослідження. Громадська думка як об’єкт дослідження сформувалася у сер. 30-х рр. ХХ ст., в період появи наукових опитувань, соціологічних анкетувань тощо. Але найголовніше, використання цих даних владою з метою формування очікуваних дій для суспільства, або відкориговування їх, особливо в передвиборчий період.

У Короткому оксфордському політичному словнику зазначається: «до загальних заяв про громадську думку, яка часто виявляється думкою двох таксистів і десятка перехожих, що йдуть один за одним, слід ставитися обережно» [6, с. 143].

Громадська думка - це форма вираження політичної волі, свідомості мас, що реально «тисне» на органи управління (у тому числі й на виборах, референдумах) $\mathrm{i}$, поряд 3 іншими соціально-політичними інститутами, бере участь у політичному процесі [8, с. 11].

Здійснивши огляд літературних джерел щодо тлумачення поняття «громадської думки», у даному дослідженні будемо використовувати його у такому значенні: вона не $є$ сумою індивідуальних думок, а виступає надіндивідуальним інтегративним утворенням, яке має історичні, часові, територіальні особливості, складну структуру і виконує певні функції [7, с. 23].

3 історії розвитку досліджень щодо питання взаємодії громадської думки та зовнішньої політики держави варто згадати праці двох ключових напрямів розрізнення відносин суспільства й держави щодо міжнародних діяльності.

Найчастіше й досить аксіоматично вирізняють лібералізм та реалізм як найбільш обгрунтовані підходи у тлумаченні необхідності залучення або врахування позицій суспільної 
думки, соціологічних рейтингів зіставлення громадян до окремих питань зовнішньої політики, настроїв громадськості з окремомого питання.

Реалістичний підхід $є$ досить консервативним та прогнозованим. Починаючи 3 праць Г. Моргентау, реалізація зовнішньої політики була сферою дії лише державних чиновників, які захищали національні інтереси від посягань інших. Такий підхід дозволяє державам розділяти суб’єктів міжнародних відносин як «своїх» та «чужих», а це, насамперед, сприяє вибору риторики перемовин з тією чи іншою групою країн, застосовування засобів різноформатної взаємодії. Сам Г. Моргентау писав, що національний інтерес $є$ категоричним імперативом, єдиним критерієм оцінювання та єдиним принципом дії у здійсненні зовнішньої політики [11].

Виходячи 3 цього, реалізації національних інтересів крізь зовнішню політику $\epsilon$ забезпеченням, насамперед, безпеки держави. П. Циганков, оцінюючи роль політичних реалістів у даному питанні, зазначає: «зовнішня політика визначається не суспільною думкою, яка б важлива вона не була, а могутністю держави, ії здатністю протистояти зовнішнім загрозам і підтриманням рівноваги сил» $[9$, с. 40$]$.

Схожу думку висловив й американський дипломат Г. Кіссінджер, оцінюючи значення тривалого періоду «холодної війни» між державами, підтримуючи факт нівелювання реагування на думку суспільства, адже воно не завжди раціонально міркує й оперує не найбільш достовірною інформацією для прийняття важливих зовнішньополітичних рішень. Він зазначає: «коли встановлений баланс між цінностями і необхідністю, зовнішньополітична діяльність повинна починатися з будь-якого визначення того, що є для країни важливі інтереси, - зміна міжнародної обстановки, трапляється, до такої міри здатна підірвати національну безпеку, що цій зміні потрібно протидіяти незалежно від іiі характеру або видимої іï законності» [4, с. 1056].

Тобто, найбільш важливим для політичної еліти $\epsilon$ визначитися із ключовими національними інтересами держави та в доступній формі провести інформативну політику для громадян, отримавши таким чином кредит довіри щодо самостійного вибору механізмів захисту саме цих національних інтересів, тим самим легітимізувавши всі свої подальші дії.

Для обгрунтування такої позиції реалісти, які формували своє бачення у консервативній та старій системі міжнародних відносин, наголошували на певних вадах врахування суспільної думки в реалізації зовнішньої політики, а саме:

1) відсутність реальної можливості врахувати думки всіх громадян, а це $є$ недостовірним відображенням суспільного;

2) відсутність стратегічного мислення й оперування до короткострокового задоволення потреб та морального стану людини;

3) відсутність в «громадській думці» компетентних оцінок та суджень щодо зовнішньої політики;

4) велика схильність до маніпулювання масовою свідомістю й, відповідно, суспільним баченням тощо.

Як доказ маніпулятивного впливу держави (в період двоблокового протистояння) Г. Кіссінджер пише: якщо демократичні країни не хотіли відтепер коливатися між крайнощами непохитностей умиротворення, то їм слід було вести свою дипломатичну діяльність в досить вузьких рамках: балансуючи між нескінченною конфронтацією, яка ставала все більш гнітючою в міру накопичення ядерних запасів обома сторонами, і такого роду дипломатією, яка заколисувала сприйняття народами «холодної війни», ситуація не покращувалась [4, с. 700].

Однак, уже в постбіполярний період, після зникнення єдиної й об'єднуючої загрози, а також із зародженням глобалізації й руйнуванням ідеологічних кордонів економічною доцільністю, перед державами постала й необхідність якісної демократизації процесу (вимога Нового світового порядку для подальшої співпраці 3 цивілізованим світом) й, відповідно, балансування національних й регіональних інтересів, окреслення перспектив розвитку для суспільств. 
Тут на порядок денний виходить лібералізм як всеохопна й безальтернативна для нових гравців міжнародних відносин ідеологія до формування як внутрішньої, так і зовнішньої політики. Вона ж і передбачала головний критерій в прийнятті рішень - враховувати позицію громадян, їх ставлення й настрої в процесі реалізації державно-владних повноважень.

Ліберальні соціологи (Б. Пейдж, Р. Шапіро й ін.) доводили, що громадській думці все ж належить здатність до послідовності, чіткості й диференціації щодо визначення проблем. Більшість авторів наголошують на раціональності, стабільності й кваліфікованості громадськості або окремих груп відповідно до тієї інформації, яка є для них доступна.

Так, у світовій політичній думці з'являється ліберальне розуміння впливу суспільної думки щодо рішень зовнішньої політики, яке отримало назву «дозвільний демократичний примус». Тобто, примус, який може дозволити чиновнику або політичному діячу переконати суспільство в необхідності того чи іншого кроку.

Загалом, і реалісти, і ліберали - це вчені двох різних реальностей, де в першому випадку панують масові загрози та їх подолання $є$ захист національних інтересів, а другі - визначають суспільне благо матеріального й емоційного характеру більш досконалими й раціональним сутностями, які варто враховувати при формуванні зовнішньої політики держави.

Звідси, сформувалисядві основні тенденції горизонтальної взаємодії влади й суспільства щодо питань формування та реалізації зовнішньої політики, а саме:

1. Суспільство визначає й впливає на дії влади шляхом активної участі в прийнятті державно-політичних рішень. Для прикладу, варто згадати про різноманітні програми залучення кваліфікованих громадських організацій до робочих груп, створення громадських рад при виконавчих органах влади, безперешкодна участь у засіданнях законотворчих палат (особливо місцевого рівня), направлення електронних петицій, які є обов'язковими для розгляду тощо. Досить часто така діяльність $є$ ефективною й дозволяє уникати різкої критики влади при ухвалені рішень.

2. Влада визначає напрями розвитку держави й пропонує їх суспільству у вигляді нормативно-правових актів (законів, меморандумів, міжнародних угод тощо). Патерналістські настрої громадян сприяють безальтернативному домінуванню влади у процесі підготовки та виробленні тактичних та стратегічних документів влади. Таким чином, вона несе відповідальність за якість та зміст життя кожного громадянина та країни загалом й, відповідно, реалізацію зовнішньополітичного курсу.

Кожна держава світу в залежності від означених тенденцій, яка переважає в ії розвитку, може бути включена певними характеристиками до одного $з$ трьох основних політичних режимів. Важливо, що «на різних етапах розвитку суспільства, у різних типах суспільств за різних політичних режимів (тоталітарних, ліберальних, демократичних) вияв громадської думки як соціальної інституції має свої особливості. Так, за тоталітарних режимів вона $є$ безсилою, за ліберальних - береться до уваги за можливістю і тільки за демократичного правління стає дійовою силою, впливаючи на всі процеси суспільного життя» [7, с. 22].

Якщо в країні, поширеним є домінування лише бюрократичного сприйняття світу, а рішення приймаються 3 метою дотримання запланованого державою програмного розвитку у вигляді стратегій, концепцій, планів, в той час як суспільство сприймає ситуацію як належне й виконує рішення влади, то така країна схильна до тоталітарного режиму. Дане суспільство не здатне на спротив та активну політичну участь, адже для виконання планових програм усі громадяни виконують лише їм призначені функції та завдання. Усі галузі працюють лише з точки зору стратегічних завдань, визначених політичною елітою або партією. 3 цією метою під контролем влади знаходиться уся пропагандистська машина, що дозволяс формувати й маніпулювати суспільною думкою. Прикладом таких держав у XXI ст. є Північна Корея, Куба, Ємен, ряд країн Африки та Південної Америки.

Іншим типом тенденцій домінування впливів влади або громадської думки на прийняття важливих державних рішень $є$ активна участь громадянського суспільства у процесі. Крім того, у 
XXI ст. зовнішньополітична активність держав пов'язана з необхідністю враховувати місце й роль нових глобальних гравців, міжнародних акторів (засоби масової інформації, транснаціональні корпорації, міжнародні урядові й неурядові організації, злочинні угрупування релігійного й ідеологічно-політичного спрямування). Тиск цих нових акторів відчувають, в першу чергу, країни, які схильні дотримуватися міжнародного права та встановлених правил міжнародної співпраці та взаємодії. Це розвинені країни Азії, Свропи, Америки.

На межі цих двох тенденцій знаходяться, за тезами 3. Бжезинського [2], геополітичні центри, а також країни, що трансформуються до демократичного політичного режиму. Україна, Грузія, Молдова, Азербайджан, Пакистан, Туреччина тощо - це група країн, які балансують між домінуванням національних інтересів й громадською думкою у процесі прийняття рішень зовнішньополітичного характеру. Часто суспільна думка стає об'єктом маніпулювання різноманітних 3MI, політичних груп, зовнішніх агентів. Але впровадження важливих механізмів й процедур (чесні вибори, незалежність ЗМІ, доступ до справедливого правосуддя й економічна стабільність) дозволяє активізувати й врахувати громадську думку у стратегічній й тактичній політико-правовій діяльності.

Враховуючи, що за тоталітарного режиму, громадська думка в сучасному іiі розумінні відсутня, варто зазначити, що маніпулятивна складова реалізації зовнішньої політики присутня й у демократичних ліберальних суспільствах. Шляхом залучення ЗМI проводиться системна інформаційна компанія на формування схвальної громадської думки щодо майбутній дій країни поза іiі межами. Для прикладу, вторгнення США в Ірак підтримувало близько 75 американців [1] як наслідок висвітлення Адміністрацією Президента Дж. Буша фактів напівдостовірного характеру щодо терористичної ядерної загрози цієї країни як для Америки, так і всього світу. «Через кілька років й відсутності доказів ядерних розробок С. Хусейном, ошуканими себе відчували більшість конгресменів, які проголосували за підтримку війни з Іраком», - напише у своій книзі «Великі рішення» Г. Клінтон [5]. Але для США позитивна громадська думка була важлива для легітимізації своїх дій й уникнення подальшого осуду міжнародного осуду.

Також більшість країни Європи на державному рівні намагалися переконати громадян у важливості членства у ЄС, а також НАТО в період підготовки процедурних і нормативних особливостей такого зовнішньополітичного курсу.

Ще одним прикладом варто назвати останні події з виходом Великобританії з ЄС, враховуючи результати референдуму, на якому британці проголосували схвально, керуючись лише лозунгами та перекрученими фактами й даними прихильників Брекситу. Уже відомо, що висвітлені показники про позитивні макроекономічні ефекти, відсоток зростання соціальноекономічного благополуччя були напівправдиві й ввели в оману британців.

Висновки й перспективи подальших досліджень. Отже, зовнішня політика крізь призму громадської думки $є$ ідеалістичним, але й реальним проявом горизонтальної взаємодії між суспільством й владою. У процесі реалізації міжнародної співпраці країна 3 одного боку маніпулює суспільним схваленням або осудом по відношенню до інших акторів або подій, а 3 іншого - легітимізує свої дії щодо них(наприклад, підписання угод, вхід або вихід з союзів, участь або невтручання у вирішенні міжнародних конфліктів).

У дослідженні були реалізовані поставлені завдання та досягнуто мети. Гіпотеза щодо місця громадської думки у XXI ст. як засобу вмілого маніпулювання та легітимізації дій влади доведена. Подальші дослідження даної теми, враховуючи отримані результати, потребують аналізу глобальної та міжнародної громадської думки (позиції), яка формується у системі взаємодії з міжнародними організаціями й суспільствами інших країн, щодо подій та діяльності держави у світі.

\section{Список використаних джерел:}


1. Арин О. Общественное мнение США о внешней политике [Электронный ресурс]/ О. Арин.- Режим доступа: http://olegarin.com/oleg-arin_articles/north-america-and-europe/us-publicopinion-on-foreign-policy.html\#ewpopup/0/. - Загл. с экрана. - Дата обращения 11.02.2017.

2. Бжезинський 3. Велика шахівниця / 3. Бжезинський. - Львів ; Івано-Франківськ: ЛілеяHB, 2000. $-236 \mathrm{c}$.

3. Качинський А. Індикатор могутності провідних країн світу: характер, тенденції та прогноз / А. Качинський, Д. Молоченко // Зовнішні справи. - 2015. - № 7. - С. 32-35.

4. Киссинджер Г. Дипломатия : [Пер. с англ.] / Г. Киссинджер. - Москва: Ладомир, 1997. $\underline{847 \mathrm{c} .}$

5. Клінтон Г. Великі рішення / Г. Клінтон ; пер. 3 англ. Л. Герасимчук. - 2-ге вид. - Київ: Наш Формат, 2016. - 544 с.

6. Короткий оксфордський політичний словник: пер. с англ. / Дж. Андергіл, П. Артур,

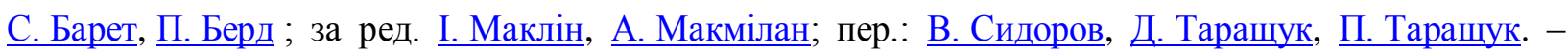
Київ: Основи, 2005. - 789 с.

7. Ляпіна Л. А. Громадська думка як соціальний феномен та іï роль у демократизації суспільних відносин / Л. А. Ляпіна, О.С.Ляпіна // Наукові праці [Чорномор. держ.ун-ту ім. П. Могили]. Серія: Соціологія. - 2011. - Т. 156, вип. 144. - С. 20-23.

8. Полторак В. А. Социология общественного мнения: [учеб. пособие] / В. А. Полторак. Киев: СОЦИОПОЛИС ; Днепропетровск: Арт-Пресс, 2000. - 264 с.

9. Цыганков П. А. Внешняя политика и общественное мнение [Электронный ресурс] / П. А. Цыганков // Обозреватель-Observer. - 2008. - № 7. - С. 36-52. - Режим доступа: https://istina.msu.ru/publications/article/3255697/

10. Шатун В. Т. Концепт громадської думки, особливості їі формування, ідентифікації та інтерпретації / В. Т. Шатун // Наукові праці [Чорномордерж.ун-ту ім. П. Могили]. Серія: Політологія. - 2012. - Т. 204, вип. 192. - С. 52-56.

11. Morgenthau, H. J. Politics Among Nations: The Struggle for Power and Peace. New York: Knopf, 2nd ed., 1954, - P. 9, 528.

\section{References:}

1. Arin, O. (2003). The US public opinion on foreign policy. [online] Available at: http://olegarin.com/oleg-arin_articles/north-america-and-europe/us-public-opinion-on-foreignpolicy.html\#ewpopup/0/. [Accessed 11 February 2017]. Title from the screen.

2. Bzhezynskyi, Z.(2000). The Grand Chessboard: American Primacy and Its Geostrategic Imperatives.Lviv, Ivano-Frankivsk: Lileia-NV.

3. Kachynskyi, A.(2015). Indicator of the power of the leading countries the world: nature, trends and prognosis. Zovnishni spravy [The UA Foreign Affairs], no. 7, pp. 32-35.

4. Kissinger, H. (1997). Diplomacy. Moscow: Ladomir.

5. Clinton, H. (2016). Hard Choices. 2nd ed. Translated from English by L.Herasymchuk. Kyiv: Nash Format.

6. Underhill, D.J., Artur, P., Barrett, S., Berd, P. eds. (2006). Concise Oxford Dictionary of Politics Translated from English by V. Sydorov, D. Tarashchuk, P. Tarashchuk. Kyiv: Osnovy.

7. Liapina, L. and Liapina, V. (2011). Public opinion as a social phenomenon and its role in the democratization of social relations. Naukovi pratsi. Chornomorskyi derzhavnyi universytet im. P. Mohyly. Seriia: Sotsiolohiia [Scientific works. Petro Mohyla Black Sea State University. Series: Sociology], Vol. 156, issue 144, pp. 20-23.

8. Poltorak, V. (2000). Sociology of public opinion. Kiev: SOTCIOPOLIS ; Dnepropetrovsk: ArtPress. 
9. Tcygankov, P. A. (2008). Foreign policy and public opinion. Obozrevatel [Observer], no. 7, pp. $36-52$.

10. Shatun, V. (2012). Concept of public opinion, especially its formation, identification and interpretation. Naukovi pratsi. Chornomorskyi derzhavnyi universytet im. P. Mohyly. Seriia: Politilohiia [Scientific works. Petro Mohyla Black Sea State University. Series: Politology],Vol. 204, issue 192, pp. 52-56.

11. Morgenthau, H.J. (1954). Politics Among Nations: The Struggle for Power and Peace. 2nd ed. New York: Knopf.

(C) Міщенко А. Б., 2018 